\title{
A new technique for inventory of permanent plots in tropical forests: a case study from lowland dipterocarp forest in Kuala Belalong, Brunei Darussalam
}

\author{
R. Hédl ${ }^{1}$, M. Svátek ${ }^{2}$, M. Dančák ${ }^{3}$, Rodzay A.W. ${ }^{4}$, M. Salleh A.B. ${ }^{4}$, Kamariah A.S. ${ }^{4}$
}

\section{Key words}

electronic compass

field-map

forest inventory

forest structure

laser rangefinder

lowland dipterocarp forest

permanent plots

taxonomic diversity

\begin{abstract}
This paper describes a new technique for inventory of permanent plots in tropical forests and presents the results of its application in a 1 ha permanent plot in a lowland dipterocarp forest at Kuala Belalong, Ulu Temburong National Park, Brunei Darussalam. The technique is based on mapping of positions of tree individuals in three-dimensional space with a high accuracy. Measuring set consists of a distance measuring device (laser rangefinder) and a electronic compass supplying data to a field computer with specialized software (Field-Map®). This method is faster and more exact than methods based on Cartesian grids established in the field. As an example, inventories from 2000 and 2007 of the plot mentioned are compared concerning presence, taxonomical identity and diameter at breast height $(\mathrm{dbh})$ of all tree individuals with $\mathrm{dbh} \geq 5 \mathrm{~cm}$. The structural and diversity properties of the forest show similar patterns to the other two permanent plots in Kuala Belalong. In 2007, 1318 trees were found, out of which 116 were new individuals (i.e. exceeded the $5 \mathrm{~cm}$ dbh limit since 2000), 13 were dead individuals. 120 trees died since 2000 (9.2\% of the trees recorded in 2000). Total basal area was $39.18 \mathrm{~m}^{2}\left(0.2 \mathrm{~m}^{2}\right.$ were dead individuals). Growth dynamics has distinct spatial patterns: about half of the plot shows fast dbh increment in 2000-2007 and appearance of numerous new trees; the other half displays stagnation. This is probably due to topographic conditions and partly to the gap dynamics (several dominant trees have fallen there since 2000). Concerning the taxonomic composition, 47 families were recorded, the dominant ones in terms of basal area being Dipterocarpaceae, Myrtaceae, Euphorbiaceae, Lauraceae, Sapotaceae and Burseraceae (sorted in decreasing order). The Dipterocarp family accounts for about $40 \%$ of the total dbh. The most frequent ones were trees of Euphorbiaceae, Dipterocarpaceae, Myrtaceae, Burseraceae and Anacardiaceae. However, this census concerns mainly trees with $\mathrm{dbh} \geq 10 \mathrm{~cm}$, while the rest $(\mathrm{dbh} 5-10 \mathrm{~cm}$ ) remained partly undetermined until 2007 .
\end{abstract}

Published on 30 October 2009

\section{INTRODUCTION}

Southeast Asian lowland dipterocarp forests (LDF), whose tree species richness exceeds 200 species per ha (Newbery et al. 1992, Poulsen et al. 1996, Leigh et al. 2004, Small et al. 2004, Condit et al. 2005), belong to the most diverse ecosystems of the world (Whitmore 1975, Ashton 2005). In Borneo, logging and forest conversion represent severe threats to the tropical rainforests (Curran et al. 2004, Sodhi et al. 2004) and lead to loss of biodiversity even within protected areas (Curran et al. 2004). Relative deforestation rate in Southeast Asia is even the highest among major tropical regions (Achard et al. 2002, Sodhi et al. 2004); therefore, it is necessary to learn as much as possible about species composition, structure and dynamics of these valuable forests before they have vanished for the greater part.

The floristic diversity of LDF has been gradually revealed and systematized thanks to the effort of tropical botanists (e.g. Whitmore 1972, Ashton 1988). Permanent plots are a standard tool to study structure and dynamics of the main constituting element of the LDF, the trees (Condit 1995, Sheil 1995). They can be re-visited and re-measured in various periods, providing

\footnotetext{
Institute of Botany, Czech Academy of Sciences, Department of Ecology, Pořičí 3b, 60300 Brno, Czech Republic; e-mail: radim.hedl@ibot.cas.cz.

Mendel University of Agriculture and Forestry, Department of Forest Botany, Dendrology and Geobiocoenology, Zemědělská 3, 613 00, Brno, Czech Republic.

${ }^{3}$ Faculty of Sciences, Palacký University, Department of Botany, Šlechtitelů 11, 78371 Olomouc, Czech Republic.

${ }^{4}$ Kuala Belalong Field Studies Centre, Universiti Brunei Darussalam, Biology Department, Jalan Tungku Link, BE1410, Brunei Darussalam.
}

data not only on floristic and structural composition, but also on forest dynamics. Standard size of many permanent plots is one hectare, which enables a direct comparison in various parameters. Phytogeographical relationships can be established using tree inventories data (e.g., Slik et al. 2003).

To assess the diversity in composition of the LDF, basic information about taxonomic identity of the trees is needed. As it is not always feasible to determine every measured tree repeatedly in each inventory, individuals are determined usually only once and labelled. The field team's task in subsequent inventories is to find all trees listed in datasheets and measure their diameters (and other parameters). New trees which have grown large enough since the last inventory have to be included. A rapid identification of the position of any tree in plot speeds up the inventory process greatly. A common tool was, and before introduction of electronic measuring devices still is, a Cartesian grid which determines the relative coordinates $(x, y)$ of tree individuals within a plot. Such a grid may be difficult to apply especially when site topography is rugged. The major concern of forest inventory is therefore to use a exact and quick method of coordinates' measurement.

Amongst other modern forest inventory methods (Holopainen \& Kalliovirta 2006), total stations combining electronic theodolite, electronic distance measuring device and computer with specialized software have recently been implemented. It enables spatially exact determination of the position of e.g. tree stems, horizontal and vertical crown projection, in three-dimensional space ( $\mathrm{x}, \mathrm{y}, \mathrm{z}$-coordinates). However, this advanced approach has been quite seldom applied so far (e.g. Vrška et al. 2002, 2006). Tree data sampling using a laser distance measuring

() 2009 Nationaal Herbarium Nederland

You are free to share - to copy, distribute and transmit the work, under the following conditions: 
device and/or electronic compass are still rare even in temperate forest ecology (Kalliovirta et al. 2005, Fajardo et al. 2007), while there are virtually no such studies from the tropical forest ecosystems.

Aim of this paper is to introduce the application of the above mentioned measuring technology in a tropical forest inventory. We will show a construction of exact spatial distribution model of trees in a plot, correcting the former specifications from the 'analogue' grid system. Herewith we will report on the vegetation patterns in the surveyed plot.

\section{MATERIAL AND METHODS}

\section{Study site}

The study site is located at the Kuala Belalong Field Studies Centre (KBFSC), a research field station of the Universiti Brunei Darussalam (http://www.ubd.edu.bn/academic/faculty/fos/ research/kbfsc/index.htm). It is situated in the Ulu Temburong National Park of Brunei Darussalam; geographic coordinates are $4^{\circ} 33^{\prime} \mathrm{N}$ and $115^{\circ} 10^{\prime} \mathrm{E}$, elevations in the KBFSC surroundings range from 60 (the station) to 913 (Bukit Belalong) $\mathrm{m}$ asl. The climate is equatorial with average temperatures around $30{ }^{\circ} \mathrm{C}$. There is no dry season (Dykes 2000) and precipitation reaches $4000 \mathrm{~mm}$. Relative air humidity exceeds $95 \%$ under the forest cover. The topography is very rugged, narrow ridges and steep slopes are the prevailing landform. Typical features are the erosion gullies dissecting the slopes. The site represents pristine lowland mixed dipterocarp forest, only slightly touched by human activities (Cranbrook \& Edwards 1994). Logging or tree felling are absent, however, occasional bark stripping in Aquilaria sp. for illegal resin collection can be observed especially along forest trails.

We carried out a 2007-inventory of Plot 1, one of four permanent 1-ha plots established at the KBFSC. Plot 1 is situated on the ridge of the Bukit Belalong, east from the Belalong River. It is bordered at two sides (zero $\mathrm{x}$ and zero y coordinates) by ridges with forest trails. Towards the opposite sides, the relief decreases following a small water stream gully. The southwest corner of the plot is the most elevated point (about $305 \mathrm{~m}$ asl); the elevation range is $27 \mathrm{~m}$ (based on our tree position measurements, z-coordinate).

We surveyed all trees in the Plot 1 . The taxonomic determination mainly relied on the data from the previous censuses in 1991, 1995 and 2000; the first and second ones included only trees with $\mathrm{dbh} \geq 10 \mathrm{~cm}$, whereas the $\geq 5 \mathrm{~cm}$ category was included in 2000. No comprehensive study from Plot 1 (and in parallel run Plot 2) was published to the present; only summary information on the composition and structure in the both plots was published in Cranbrook \& Edwards (1994). Inventories from two other 1-ha plots, situated on the slopes west from the Belalong River, were however published by Poulsen et al. (1996) and Small et al. (2004). Osunkoya et al. (2007) related wood properties with demography (mortality) of 27 tree species from the latter plot.

\section{Inventory methodology}

Within Plot 1 , positions of all trees $\geq 5 \mathrm{~cm}$ dbh were mapped (procedure see below), and the diameter of each tree was measured at breast height, i.e. $1.3 \mathrm{~m}$ above ground (or just above buttresses if present). The point of diameter measurement was marked on the stem with a red paint line. Dbh was measured using a girthing tape giving directly dbh values, which were immediately stored in the field Hammerhead computer running a specialized software, Field-Map ${ }^{\circledR}$ v3.151 (the Institute of Forest Ecosystem Research, Ltd. (IFER), Jílové u Prahy, Czech Republic; www. fieldmap.cz), together with other tree's characteristics - ID number, note on current status (e.g., dead) and coordinates. The coordinates were recorded using a set of interconnected devices: laser rangefinder Impulse 200 Standard, electronic compass MapStar Module II (both Laser Technology Inc., Colorado, USA), and field Hammerhead computer (WalkAbout Computers, West Palm Beach, Florida, USA). The measuring set was assembled on a portable monopod frame.

The person operating the measuring device was accompanied by at least 1 (preferably 2) persons holding and moving 2-m range pole(s) with a mounted reflector. Starting the measurements, the initial position of the measuring equipment within the plot was chosen in such a way that the post marking the plot corner was visible. To adapt the electronic compass to the local magnetic environments, it was field-calibrated following the manufacturer's instructions. The distance and the azimuth from the initial position to a pole-mounted reflector at the corner post were then measured by the laser rangefinder and the compass respectively, thus allowing positioning of the measuring equipment in subsequent plot re-measurements. In the mapping software, the $x, y$ and $z$ coordinates of the initial position of the equipment were $0,0,0$; thus the positions of trees and all other points within the plot were measured in relative coordinates.

Main task of the inventory, determining tree positions, was accomplished in the following days; the laser rangefinder was used for measuring the distance from the position of the measuring set to a reflector on a pole which was put to the surface of a tree stem, while the electronic compass measured horizontal angles (i.e. azimuth) simultaneously. Running the Field-Map software, position of each tree (i.e. $x, y$, and thanks to the built-in tilt sensor of the laser rangefinder also $z$-coordinate) was automatically recorded to the computer and immediately displayed on the screen as a two-dimensional map. Tree numbers stored in the Field-Map software followed the tags nailed to trees in previous inventories. New trees, reaching the $\geq 5 \mathrm{~cm} \mathrm{dbh}$ by 2007 , were labelled with a new aluminium tag.

After all trees visible from the initial position were measured, the measuring set was repositioned within the plot using two reference points. Reference points were usually represented by trees near the limit of visibility. The distance and the azimuth to two reference points were measured from the original position; subsequently the measuring equipment was moved to a new position from which the distance and the azimuth to the same two reference points were measured. Thus the system of reference points established in the field allowed to move freely and quickly reposition the measuring set within the plot, while keeping spatial reference. To convert local (relative) coordinates of the plot to global coordinates, those reference points which can be permanently fixed in the field (e.g. corner posts), shall be measured not only by laser and compass but also by GPS.

Taxonomic determination relied mostly on the initial inventories in the 1990s, which were to species level in the most cases. Therefore, most large and intermediate-sized trees are taxonomically well-identified. Trees with a diameter less than $10 \mathrm{~cm}$, included in the inventory in 2000 , are determined only from a part. We corrected or supplemented taxonomic identity (usually only family) of about 70 individuals directly in the field. Herbarium specimens of other 242 undetermined trees were collected in February 2009. Determination was completed by the Brunei Forestry Centre National Herbarium in June 2009 (data not included in this paper).

The timespan for the field inventory was ten days in JanuaryFebruary 2007. It included also positioning, i.e. i) moving the standpoint of the measuring set and determining its position again; and ii) searching for trees indicated in the datasheets. 
The latter took about half of the total measurement time, pointing out the need for exact and readily available data on each tree position.

\section{Data treatment and analyses}

Sorting the datasheet was a time-consuming task. Coordinates and $\mathrm{dbh}$ were continuously downloaded from Field-Map to a Microsoft Excel table. It was necessary to match the trees from the previous and the current inventory, because many trees lost their tags since 2000 and new tags (numbers) were attached in 2007. Sometimes the tree positions measured using the field grid (1991, 1995 and 2000) did not match the coordinates measured using the electronic device (2007). Identifying especially the thin trees was inevitably an arbitrary decision in several cases. From the datasheet, it was derived which trees died, either found (their positions not always measured) or not found again; and which trees were newly included in the inventory, reaching $\mathrm{dbh} \geq 5 \mathrm{~cm}$. For construction of threedimensional models of the plot we used $x-y$-z-coordinates data from the concluding datasheet. The figure was created using spline interpolation in ArcView 3D Analyst and ArcScene v8.3 (ESRI®).

Statistical analyses provided in this paper are very basic. We computed the following parameters (cf. Small et al. 2004) for the 2000 and 2007 inventories:

-individual basal area $\left(B A_{i}\right)$, using the formula $\Pi(d / 2)^{2} \cdot 10^{-4}$

$\left[\mathrm{m}^{2}\right]$, where $\mathrm{d}$ is the tree $\mathrm{dbh}$ in $\mathrm{cm}$;

- family density $\left(D_{f}\right)$, the number of individuals determined to the family level, for each family;

- family basal area $\left(\mathrm{BA}_{\mathrm{f}}\right)$, summing up the $\mathrm{BA}_{\mathrm{i}}$ within families, for taxonomically determined trees;

- family relative density, computed as $\left(D_{f} / N\right) .100[\%]$, where $N$ is the total number of trees determined at least to the family level;

- family relative dominance, computed as $\left(\mathrm{BA}_{\mathrm{f}} / \mathrm{BA}_{\mathrm{t}}\right) .100[\%]$, where $B A_{t}$ is the basal area of all trees determined at least to the family level.

Except for the $\mathrm{BA}_{\mathrm{i}}$, information on taxonomy is needed. In Plot 1 , nearly half of the individuals remain undetermined (636 out of 1318 ). The majority of them are the smallest trees with $\mathrm{dbh}<10$ $\mathrm{cm}$. The respective analyses (table and graphs) are therefore valid for 682 trees with identification to at least family level, a subset approximately equal to trees with $\mathrm{dbh} \geq 10 \mathrm{~cm}$.

\section{RESULTS}

\section{Structure and composition}

In 2007, we measured 1318 trees with $\mathrm{dbh} \geq 5 \mathrm{~cm}$, out of which 116 were new individuals (i.e. exceeded the $5 \mathrm{~cm}$ dbh limit since 2000 ) and 13 were dead individuals. Altogether 120 trees died since 2000 , i.e. $9.2 \%$ of the trees recorded in 2000 . Basal area of all trees measured in 2007 was $39.2 \mathrm{~m}^{2}$, from which $0.2 \mathrm{~m}^{2}$ was constituted by dead individuals (Table 1 ). Average $\mathrm{dbh}$ in 2007 was $13.9 \mathrm{~cm}$, the highest measured $152.8 \mathrm{~cm}$; distribution of dbh is shown in Fig. 1 (this output is also provided directly by the Field-Map software).

Three-dimensional model of the plot based on the tree coordinates is shown in Fig. 2. Dots representing individual trees are distinguished according to the dbh. The largest, dominant trees of the forest canopy (dbh 50-153 cm) concentrate in the upperelevated parts of the plot, i.e. sides following the ridges.

Concerning taxonomic composition, 47 families were present in the plot. Fifteen dominant families with the measured basal area of $0.5 \mathrm{~m}^{2}$ and more (based on individuals determined at least to family level) were Anacardiaceae, Burseraceae, Clusiaceae, Dipterocarpaceae, Ebenaceae, Euphorbiaceae, Flacourtiaceae, Lauraceae, Moraceae, Myristicaceae, Myrtaceae, Sapindaceae, Sapotaceae, Sterculiaceae and Tiliaceae; they comprised $90 \%$ of the basal area of the determined individuals. The top seven of nine trees with dbh exceeding $80 \mathrm{~cm}$ belonged to the genus Shorea (Dipterocarpaceae); records from all four inventories are concerned. Six most abundant families with more than 30 determined individuals in 2007 were Anacardiaceae, Burseraceae, Dipterocarpaceae, Euphorbiaceae, Myristicaceae and Myrtaceae; they accounted for nearly $60 \%$ of the determined individuals. For values see Table 1. Relationships in relative density and dominance are shown in Fig. 3. Prevalence of Dipterocarpaceae, occupying more than $40 \%$ of the basal area, is apparent. We assume that the ranks and percentages would not change substantially if all individuals were determined.

The largest recent losses in basal area were recorded for Dipterocarpaceae where two big Shorea trees have fallen down since 2000, opening the canopy gaps. Similar changes could be observed in Sapotaceae where two larger trees of 50-70 $\mathrm{cm}$ dbh died and in Anacardiaceae where several intermediate-sized trees (Gluta oba, Mangifera sp.) have not survived until 2007. On the other hand, Euphorbiaceae and Clusiaceae increased moderately in the basal area, despite the decrease in number of their individuals since 2000 .

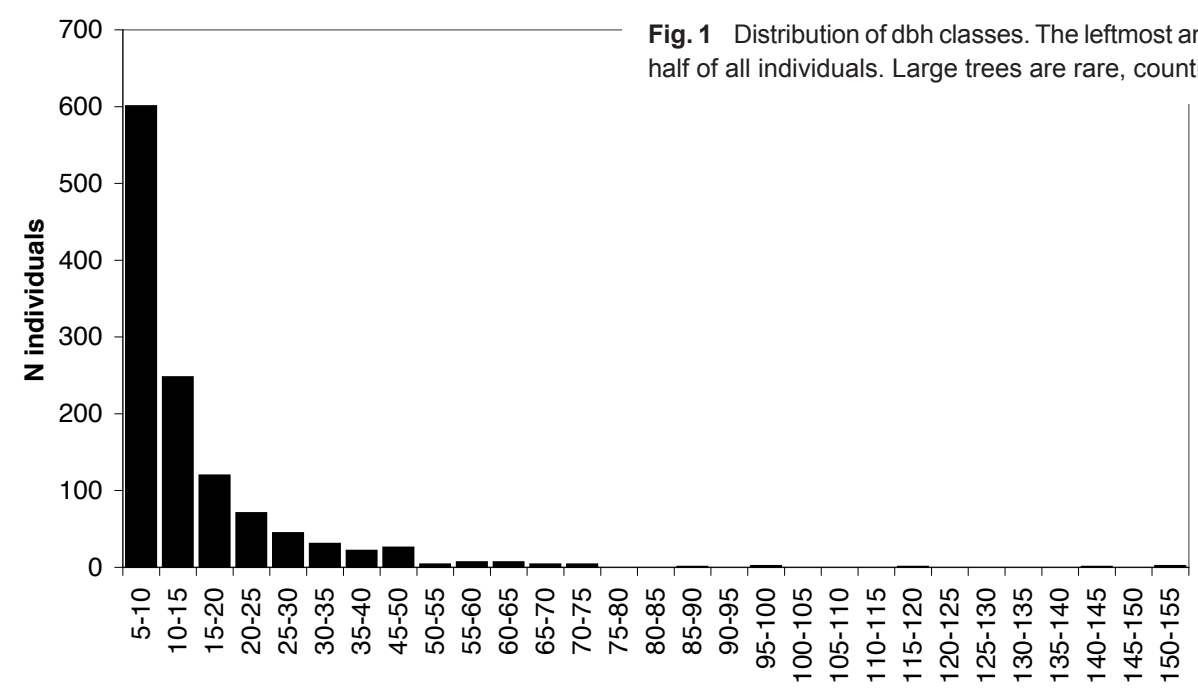

DBH classes $(\mathrm{cm})$ 
Table 1 Summary table for forty-seven tree families determined in plot in 2000 and 2007. Number of individuals $(\mathrm{N})$, basal area $\left(B A ; \mathrm{m}^{2}\right)$ and change of $B A\left(\mathrm{~m}^{2}\right)$ are shown.

\begin{tabular}{|c|c|c|c|c|c|}
\hline Family & $N(2000)$ & $\mathrm{BA}(2000)$ & $N(2007)$ & $\mathrm{BA}(2007)$ & change(BA) \\
\hline Alangiaceae & 3 & 0.08 & 2 & 0.05 & -0.027 \\
\hline Anacardiaceae & 45 & 1.27 & 39 & 0.94 & -0.334 \\
\hline Annonaceae & 5 & 0.11 & 5 & 0.12 & 0.015 \\
\hline Apocynaceae & 1 & 0.08 & 1 & 0.09 & 0.006 \\
\hline Aquilariaceae & 2 & 0.09 & 2 & 0.10 & 0.010 \\
\hline Barringtoniaceae & 2 & 0.02 & 2 & 0.02 & 0.003 \\
\hline Bombacaceae & 2 & 0.01 & 2 & 0.01 & 0.000 \\
\hline Burseraceae & 43 & 1.14 & 40 & 1.16 & 0.022 \\
\hline Celastraceae & 14 & 0.43 & 13 & 0.46 & 0.031 \\
\hline Clusiaceae & 17 & 0.96 & 16 & 1.12 & 0.164 \\
\hline Crypteroniaceae & 1 & 0.02 & 1 & 0.03 & 0.006 \\
\hline Dilleniaceae & 5 & 0.16 & 4 & 0.17 & 0.003 \\
\hline Dipterocarpaceae & 109 & 16.93 & 103 & 14.94 & -1.993 \\
\hline Ebenaceae & 25 & 0.49 & 23 & 0.50 & 0.009 \\
\hline Elaeocarpaceae & 2 & 0.05 & 2 & 0.06 & 0.018 \\
\hline Euphorbiaceae & 162 & 3.23 & 153 & 3.42 & 0.189 \\
\hline Fagaceae & 4 & 0.28 & 1 & 0.16 & -0.127 \\
\hline Flacourtiaceae & 33 & 0.84 & 29 & 0.68 & -0.160 \\
\hline Gonystylaceae & 1 & 0.03 & 1 & 0.03 & 0.004 \\
\hline Icacinaceae & 4 & 0.10 & 4 & 0.10 & 0.004 \\
\hline Lauraceae & 25 & 1.24 & 24 & 1.23 & -0.012 \\
\hline Leguminosae & 12 & 0.24 & 11 & 0.33 & 0.089 \\
\hline Magnoliaceae & 1 & 0.01 & 1 & 0.01 & 0.000 \\
\hline Melastomataceae & 3 & 0.02 & 2 & 0.03 & 0.004 \\
\hline Meliaceae & 7 & 0.18 & 7 & 0.21 & 0.028 \\
\hline Memecylaceae & 6 & 0.51 & 4 & 0.25 & -0.256 \\
\hline Moraceae & 15 & 0.73 & 13 & 0.64 & -0.087 \\
\hline Myristicaceae & 38 & 0.95 & 33 & 0.87 & -0.085 \\
\hline Myrsinaceae & 1 & 0.03 & 1 & 0.03 & 0.001 \\
\hline Myrtaceae & 51 & 3.60 & 50 & 3.51 & -0.090 \\
\hline Naucleaceae & 1 & 0.06 & 1 & 0.06 & 0.000 \\
\hline Olacaceae & 2 & 0.03 & 2 & 0.04 & 0.003 \\
\hline Oleaceae & 1 & 0.02 & 1 & 0.02 & 0.005 \\
\hline Polygalaceae & 4 & 0.10 & 3 & 0.09 & -0.009 \\
\hline Rhizophoraceae & 4 & 0.08 & 3 & 0.08 & -0.007 \\
\hline Rubiaceae & 15 & 0.22 & 15 & 0.24 & 0.015 \\
\hline Rutaceae & 1 & 0.02 & 1 & 0.02 & 0.003 \\
\hline Sapindaceae & 11 & 0.56 & 11 & 0.63 & 0.074 \\
\hline Sapotaceae & 31 & 1.57 & 29 & 1.17 & -0.401 \\
\hline Sterculiaceae & 10 & 0.85 & 10 & 0.91 & 0.060 \\
\hline Stilaginaceae & 2 & 0.02 & 2 & 0.02 & 0.000 \\
\hline Symplocaceae & 1 & 0.01 & 1 & 0.01 & 0.000 \\
\hline Tetrameristaceae & 1 & 0.20 & 1 & 0.21 & 0.011 \\
\hline Theaceae & 2 & 0.05 & 2 & 0.06 & 0.004 \\
\hline Tiliaceae & 3 & 0.63 & 3 & 0.71 & 0.087 \\
\hline Ulmaceae & 7 & 0.18 & 7 & 0.20 & 0.012 \\
\hline Verbenaceae & 1 & 0.01 & 1 & 0.01 & 0.000 \\
\hline determined & 736 & 38.42 & 682 & 35.71 & -2.707 \\
\hline undetermined & 569 & 2.73 & 636 & 3.46 & 0.737 \\
\hline total & 1305 & 41.15 & 1318 & 39.18 & -1.970 \\
\hline
\end{tabular}

\section{Dynamics}

Total basal area decreased by $2.0 \mathrm{~m}^{2}$ since the 2000 inventory which recorded the total basal area as $41.2 \mathrm{~m}^{2}$, which is due to the fall of the large trees mentioned above. The tree growth dynamics is demonstrated in Fig. 4, showing the relationship between the actual $\mathrm{dbh}$ and its increment since 2000. The largest size gains recorded intermediate-sized individuals with $\mathrm{dbh}$ of $20-70 \mathrm{~cm}$. Nevertheless, some small individuals with $\mathrm{dbh}$ of $10 \mathrm{~cm}$ can also grow rapidly (dbh increments by 5-6 $\mathrm{cm})$. On the other hand, large-sized trees slowed down their growth. This figure, however, does not show the spatial pattern which is, according to our field experience, mainly influenced by canopy gaps dynamics. A basic picture of these processes provides Fig. 5; the fastest dbh increments are located in the lower elevations of the plot (higher values of the xy coordinates); they are closely linked with the emergence of the new trees (exceeding dbh of $5 \mathrm{~cm}$ since 2000). On the other hand, the lowest girth increase occur mainly in the opposite, higherelevated part of the plot (lower values of the xy coordinates). These trees are accompanied by trees which recorded a negative dbh increment, which probably reflects stagnation in trees' growth. Apparently, forest dynamics displays spatial patterns exceeding the 'window' captured by the 1-ha plot.

\section{DISCUSSION}

\section{Inventory method}

The classical inventory method is based on mapping the trees' positions using a regular (Cartesian) grid. Corners of usually $10 \mathrm{~m}$ subplots are temporarily marked to make the inventory easier (e.g., Newbery et al. 1992, Small et al. 2004, Osunkoya et al. 2007). Measuring with tape and compass can produce numerous mistakes and inexact coordinates determination. The main advantage of the method used by us is exact and consistent determination of the trees' position in a three-dimensional space (z-coordinate for relative elevation).

Contrary to expectations, the dense forest was not a major obstacle for tree position measurement. Even in a rather dense growth, the laser rangefinder worked at distances up to 20 to $30 \mathrm{~m}$. Climatic conditions should not represent an obstacle to measurements, as all devices are water-proof. The only problem we experienced was with the Hammerhead computer, as we used an old one, which was not water-proof and needed to be dried up after rain.

Fig. 2 Three-dimensional model of Plot 1 derived from trees' coordinates. Dots represent trees' positions, the size following dbh. The canopy trees occur more frequently in the topographically higher positioned sites.

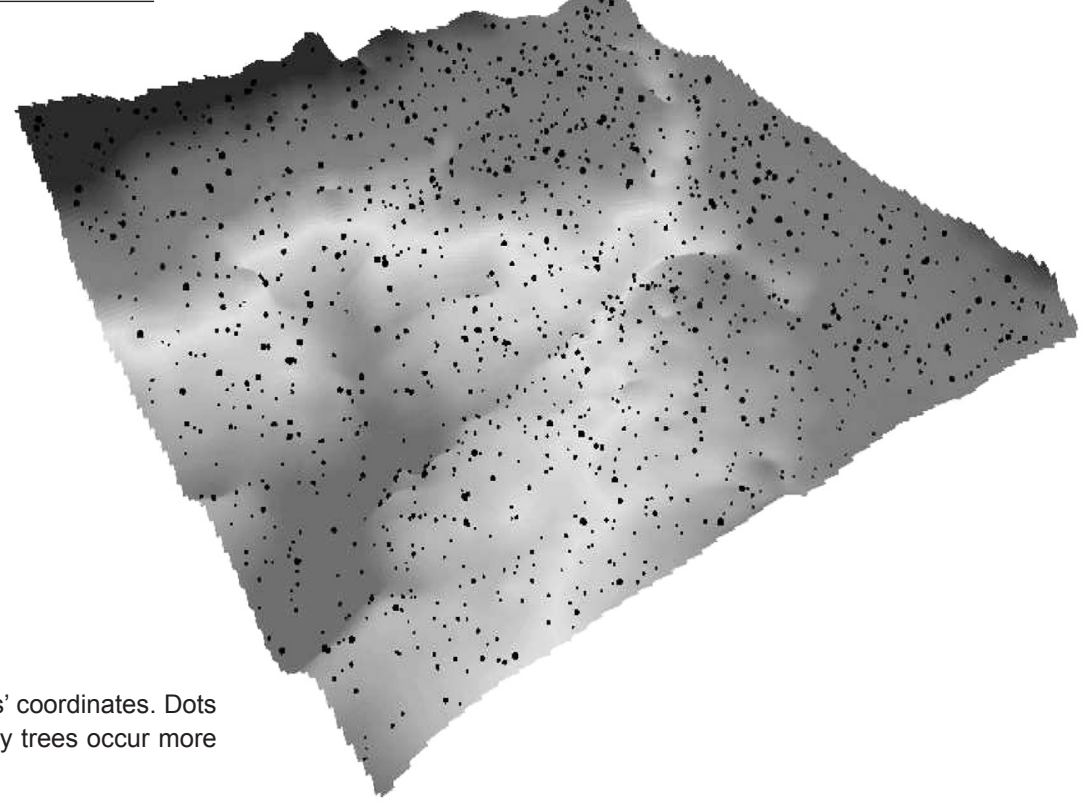




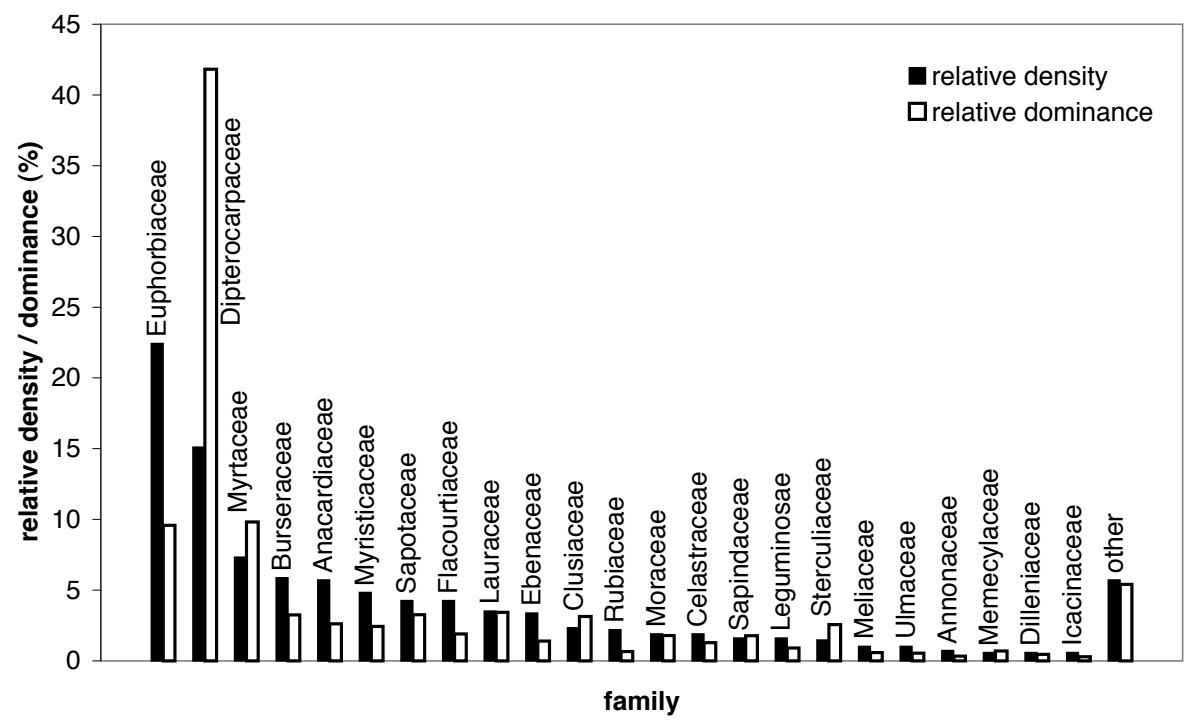

Fig. 3 Relative density and relative dominance of families in 2007 . The graph is for 682 trees with identification to at least family level, a subset approximately equal to trees with $\mathrm{dbh} \geq 10 \mathrm{~cm}$. Twenty-three familes are pictured, the other 24 are merged in category 'other' (following the rank of relative density).

Once having a plot measured, the repetition is easier and quicker than with standard methodology. Trees are much easier to be found again, because the field computer shows the distribution on the screen. The selected tree can be highlighted in the digital map; distance and direction to the next surveyed individual can be quickly determined. In our inventory, we spent about half of the inventory time searching for trees located, often erroneously, compared to previous inventories. It was quite difficult to use the datasheet and field marking for orientation. When a realistic, computer produced map and exact coordinates are used in the inventory, the time can be reduced to $2 / 3$ or even a half, i.e. 5-7 working days in our case. Outside the rainy season the average measurement time is 5 hours a day, so a precise and reliably repeated inventory of a 1-ha plot of the lowland dipterocarp forest can be completed in 4-6 days.

Two persons are needed to measure the tree position - one to operate the computer, laser and compass devices, another to hold and move the pole with the reflector. If the conditions allow, one more pole-operator can make the process go quicker. One person is needed to measure the $\mathrm{dbh}$, although this can be easily done by the reflector pole operator as well. One per- son should sample the herbarium specimens from the newly included trees (grown over $5 \mathrm{~cm}$ dbh since the last inventory). This can be done also independently from the measurements. In total, a group of two to five people are the recommended working group for this survey.

\section{Structural patterns}

We compared the observed structural and taxonomic patterns to inventories carried out by Poulsen et al. (1996) and Small et al. (2004). The former concerns a 1-ha plot established and surveyed in 1991 by the Aarhus University ('AAU1' plot); trees with $\mathrm{dbh} \geq 10 \mathrm{~cm}$ were included. The latter is a plot established in 1995 by the Earthwatch Institute and the Universiti Brunei Darussalam Kuala Belalong Field Studies Centre ('the Earthwatch plot') and surveyed for all trees with $\mathrm{dbh} \geq 5 \mathrm{~cm}$ in 1995 and 2004 (Osunkoya et al. 2007). Both 1-ha plots are situated west of the Belalong River, the former on the foothill in elevations of $55-80 \mathrm{~m}$ asl $(0.75 \mathrm{~km}$ from Plot 1$)$, the latter on the slope above it in about $250 \mathrm{~m}$ asl (about $1.25 \mathrm{~km}$ from Plot 1). Both number and basal area of live trees in Plot 1 were higher than in the Earthwatch plot (Small et al. 2004), while the opposite was true for dead stems (see Table 2). The same

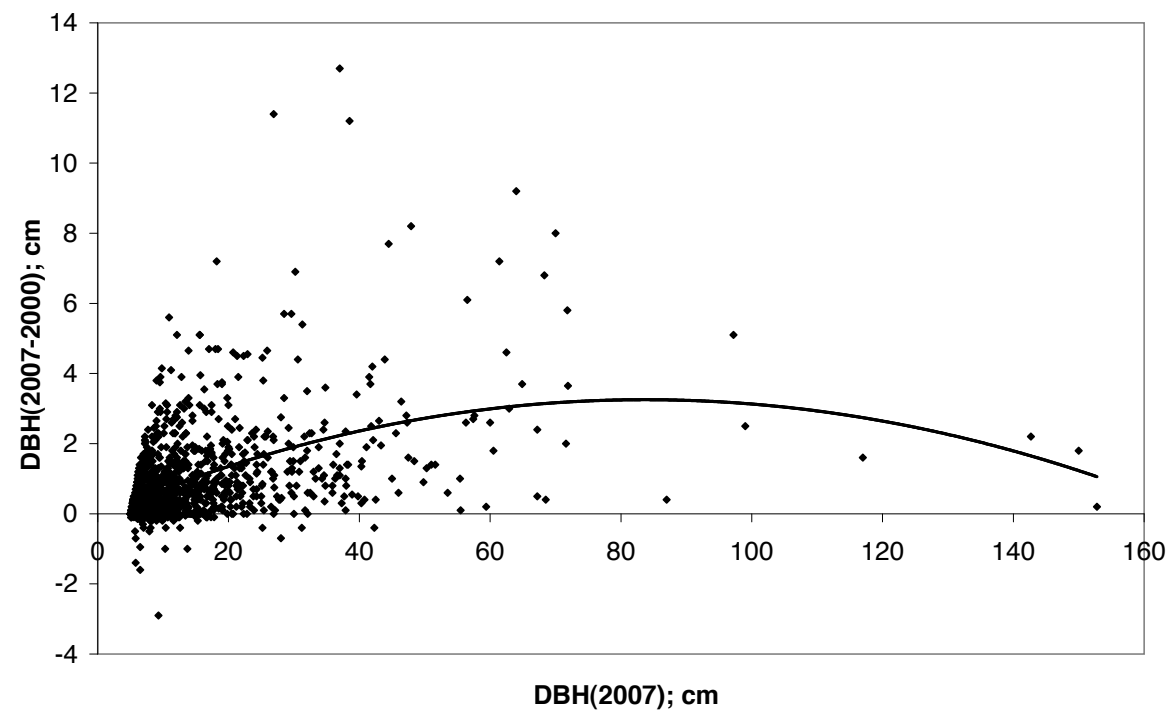

Fig. 4 The recent tree growth dynamics: Relationship between the actual dbh and dbh change since 2000. The radial growth gradually drops with age. The fastest growing are smaller trees with dbh $10-20 \mathrm{~cm}$; the largest timber volume increments recorded intermediate-sized trees with dbh $20-70 \mathrm{~cm}$. 
Table 2 Comparison of structural characteristics between the Earthwatch plot and Plot 1. Both for live and dead individuals, number ( $\mathrm{N}$ ) and basal area $\left(B A ; \mathrm{m}^{2}\right)$ are presented. The average and maximum $\mathrm{dbh}(\mathrm{cm})$ for both plots are shown.

\begin{tabular}{lccccc}
\hline Site & N (live) & N (dead) & BA (live) & BA (dead) & Average dbh \\
\hline Earthwatch plot (Small et al. 2004) & 1019 & 43 & 31.4 & 0.9 & 14.0 \\
Plot 1 (2007, this paper) & 1305 & 13 & 39.0 & 0.2 & 186.0 \\
\hline
\end{tabular}

table shows that the highest recorded dbh was higher in the lower positioned Earthwatch plot; however the average dbh was almost the same for both plots.

Taxonomic richness is very similar to the Earthwatch plot, however, only the dominant families correspond between the two plots. Families encountered only once or twice are from a greater part different, indicating the relatively high beta-diversity of the local forests. Altitude plays the main role, which was shown by Poulsen \& Pendry (1995) for the ground herbs at the Bukit Belalong. The same seems to be true for trees also in relatively short altitudinal gradients. However, direct comparison of taxonomic composition is constrained due to the fact that nearly half of the tree individuals in Plot 1 remained undetermined to family level in 2007 . They were almost all small in size, mainly with dbh under $10 \mathrm{~cm}$. This is reflected in the basal areas of the determined $\left(35.7 \mathrm{~m}^{2}\right)$ and undetermined $\left(3.5 \mathrm{~m}^{2}\right)$ individuals. Hence, species diversity can be estimated quite precisely for the grown trees with $\mathrm{dbh} \geq 10 \mathrm{~cm}$; regeneration dynamics of the forest cannot be analysed regarding the taxonomic information, which however remains true for the most inventories - only scarcely the saplings ( $\mathrm{dbh} \geq 1 \mathrm{~cm}$ ) have been included (e.g., Condit 1995).

Based on tree individuals with $\mathrm{dbh} \geq 10 \mathrm{~cm}$, a brief comparison of the forest composition and structure in Plots 1, 2 and AAU1 was provided by Cranbrook \& Edwards (1994: 103-104). All the mentioned plots in Kuala Belalong document the forest dominated with the Dipterocarpaceae (basal area) and Euphorbiaceae (number of individuals). The three plots comprised from 550 (AAU1, see Poulsen et al. 1996) to 656 individuals and slightly more than 40 families (43 for AAU1). In 2007, we found 601 trees with $\mathrm{dbh} \geq 10 \mathrm{~cm}$ in Plot 1 , out of which 6 were dead stems. In AAU1, this number was 550 trees (Poulsen et al.
1996); however, only 422 live individuals fell in the same dbhsubset from the Earthwatch plot (Small et al. 2004). This basically conforms the results from other inventories in South East Asian lowland rainforests, e.g. East Kalimantan (Yamakura et al. 1986) with 550 individuals and a basal area of $32.8 \mathrm{~m}^{2}$. Variance can be documented by Sumatran forest with 755 individuals and a basal area of $44.4 \mathrm{~m}^{2}$ per hectar (Trichon et al. 1998 ) and a dipterocarp forest in Danum Valley, N Borneo, with 470 individuals and a basal area of $26.6 \mathrm{~m}^{2}$ (Newbery et al. 1992).

\section{CONCLUSIONS}

Application of an electronic device set (a total station) for the 2007-inventory of Plot 1 lead to the precision of the data, leaving a readily available dataset for the next inventory. Similar structural and taxonomic patterns in trees as in other plots in Kuala Belalong, the Aarhus plot (AAU1) and the Earthwatch plot, were shown. A pattern of the forest dynamics in Plot 1 was outlined. It is possibly dependent on site topography and intrinsic demographic processes, while a proper study in terms of the analysis of subsequent inventories would be needed to elucidate this. Three directions of the future research in Kuala Belalong based on the current inventories can be suggested: i) study of the taxonomic patterns between the plots, i.e. the beta-diversity and the determining site factors (altitude, position on the slope); ii) study of the long-term forest dynamics based on analysis of demographic data from the subsequent inventories (1991, 1995, 2000, 2007, etc.); iii) study of the fine spatial patterns in forest dynamics, linked with topographic and demographic variables.

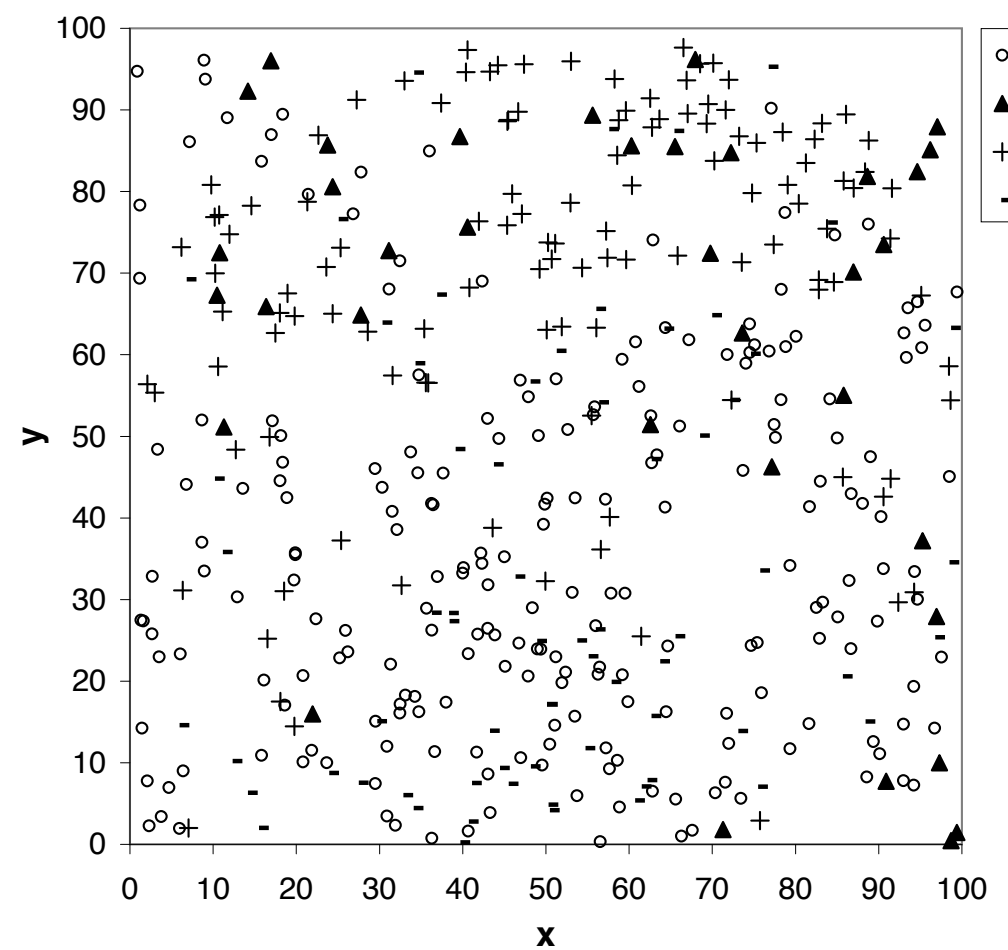

$0-0.1$

4.0-12.7

+ new

- negat.
Fig. 5 Recent growth dynamics: dbh increments $(\mathrm{cm})$ in two extreme categories. Negative increment ('negat.') denotes trunks with dbh lower in 2007 than in 2000, 'new' are the trees entering the inventory in 2007 (reaching $\mathrm{dbh} \geq 5 \mathrm{~cm}$ ). Fast growing trees can be observed in the upper part of the diagram, while stagnation prevails in the lower part (upper right corner is in the direction of the gully, see Fig. 2). 
Acknowledgements We are obliged to several persons and institutions who initiated and enabled our research stay at KBFSC. They are Earl of Cranbrook; David S. Edwards (Universiti Brunei Darussalam); and Nigel Winser (Earthwatch Institute). We also thank Rafhiah $\mathrm{Hj}$. Abdul Kahar and Hajah Masnah $\mathrm{Hj}$. Mirasan from UBD, and volunteer students who helped us in the fieldwork. Finally our thanks go to the editor of this paper P. Hovenkamp whose comments have lead to an improvement of the text. This publication was supported by the institutional long-term research plan, grant No. AV0Z60050516 of the Academy of Sciences of the Czech Republic $(\mathrm{RH})$ and by the Institutional Research Plan MSM 6215648902/04/01/04.

\section{REFERENCES}

Achard F, Eva HD, Stibig HJ, Mayaux P, Gallego J, Richards T, Malingreau JP. 2002. Determination of deforestation rates of the world's humid tropical forests. Science 297: 999-1002.

Ashton PS. 1988. Manual of the non-dipterocarp trees of Sarawak. Forest Department, Sarawak, Malaysia.

Ashton PS. 2005. Lambir's forest: The world's most diverse known tree assemblage? In: Roubik D, Sakai S, Hamid AA (eds), Pollination ecology and the rain forest. Ecological Studies 174: 191-216. Springer, Berlin Heidelberg.

Condit R. 1995. Research in large, long-term tropical forest plots. Trees 10: 18-22.

Condit R, Ashton PS, Balslev H, Brokaw N, Bunyavejchewin S, Chuyong G, Co L, Dattaraja HS, Davies S, Esufali S, Ewango CEN, Foster R, Gunatilleke N, Gunatilleke S, Hernandez C, Hubbell S, John R, Kenfack D, Kiratiprayoon S, Hall P, Hart T, Itoh A, Lafrankie JV, Liengola I, Lagunzad D, Lao S, Losos E, Magard E, Makana J, Manokaran N, Navarrete H, Mohammed Nur S, Okhubo T, Pérez R, Samper C, Hua Seng L, Sukumar R, Svenning JC, Tan S, Thomas D, Thompson J, Vallejo M, Villa G, Muñoz Valencia R, Yamakura T, Zimmerman J. 2005. Tropical tree $\alpha$-diversity: Results from a worldwide network of large plots. Biologiske Skrifter 55: 565-582.

Cranbrook Earl of, Edwards DS. 1994. A tropical rainforest. The nature of biodiversity in Borneo at Belalong, Brunei. The Royal Geographical Society and Sun Tree Publishing, London and Singapore.

Curran LM, Trigg SN, McDonald AK, Astiani D, Hardiono YM, Siregar P, Caniago I, Kasischke E. 2004. Lowland forest loss in protected areas of Indonesian Borneo. Science 303: 1000-1003.

Dykes AP. 2000. Climatic patterns in a tropical rainforest in Brunei. The Geographical Journal 166: 63-80.

Fajardo A, Graham JM, Goodburn JM, Fiedler CE. 2007. Ten-year responses of ponderosa pine growth, vigor, and recruitment to restoration treatments in the Bitterroot Mountains, Montana, USA. Forest Ecology and Management 243: 50-60.

Holopainen M, Kalliovirta J. 2006. Modern data acquisition for forest inventories. In: Kangas A, Maltamo M (eds), Forest inventory - methodology and applications: 343-362. Springer, The Netherlands.
Kalliovirta J, Laasasenaho J, Kangas A. 2005. Evaluation of the Laser-relascope. Forest Ecology and Management 204: 181-194.

Leigh Jr EG, Davidar P, Dick CW, Puyravaud JP, Terborgh J, Ter Steege H, Wright J. 2004. Why do some tropical forests have so many species of trees? Biotropica 36: 447-473.

Newbery DMcC, Campbell EJF, Lee YF, Ridsdale CE, Still MJ. 1992. Primary lowland dipterocarp forest at Danum Valley, Sabah, Malaysia: structure, relative abundance and family composition. Philosophical Transactions of the Royal Society of London, series B 335: 341-356.

Osunkoya OO, Sheng TK, Mahmud NA, Damit N. 2007. Variation in wood density, wood water content, stem growth and mortality among twentyseven tree species in a tropical rainforest on Borneo Island. Australian Journal of Ecology 32: 191-201.

Poulsen AD, Nielsen I, Tan S, Balslev H. 1996. A quantitative inventory of trees in one hectare of mixed dipterocarp forest in Temburong, Brunei Darussalam. In: Edwards DS, Booth WE, Choy SC (eds), Tropical rainforest research - current issues, Monographiae Biologicae 74: 139-150.

Poulsen AD, Pendry CA. 1995. Inventories of ground herbs at three altitudes on Bukit Belalong, Brunei, Borneo. Biodiversity and Conservation 4: 745-757.

Sheil D. 1995. A critique of permanent plot methods and analysis with examples from Budongo forest, Uganda. Forest Ecology and Management 77: 11-34.

Slik JWF, Poulsen AD, Ashton PS, Cannon CH, Eichhorn KAO, Kartawinata K, Lanniari I, Nagamasu H, Nakagawa M, Van Nieuwstadt MGL, Payne J, Purwaningsih, Saridan A, Sidiyasa K, Verburg RW, Webb CO, Wilkie P. 2003. A floristic analysis of the lowland dipterocarp forests of Borneo. Journal of Biogeography 30: 1517-1531.

Small A, Martin TG, Kitching RL, Wong KM. 2004. Contribution of tree species to the biodiversity of a 1 ha Old World rainforest in Brunei, Borneo. Biodiversity and Conservation 13: 2067-2088.

Sodhi NS, Koh LP, Brook BW, Ng PKL. 2004. Southeast Asian biodiversity: an impending disaster. Trends in Ecology and Evolution 19: 654-660.

Trichon V, Walter J-MN, Laumonier Y. 1998. Identifying spatial patterns in the tropical rain forest structure using hemispherical photographs. Plant Ecology 137: 227-244.

Vrška T, Adam D, Hort L, Odehnalová P, Horal D, Král K. 2006. Developmental dynamics of virgin forests reserves in the Czech Republic. II. Floodplain forests - Cahnov-Soutok, Ranšpurk, Jiřina. Academia, Prague.

Vrška T, Hort L, Adam D, Odehnalová P, Horal D. 2002. Developmental dynamics of virgin forests reserves in the Czech Republic. I. Českomoravská vrchovina Upland - Polom, Žákova hora Mt. Academia, Prague.

Whitmore TC (ed). 1972. Tree flora of Malaya. Vol. 1. Longman, London.

Whitmore TC. 1975. Tropical rain forests of the Far East. Clarendon Press, Oxford, United Kingdom.

Yamakura T, Hagihara A, Sukardjo S, Ogawa H. 1986. Aboveground biomass of tropical rain forest stands in Indonesian Borneo. Vegetatio 68: 71-82. 